\title{
The response of hind-limb muscles of the weanling rat to undernutrition and subsequent rehabilitation
}

\author{
By J. W. T. DICKERSON \\ Department of Biochemistry, University of Surrey, Guildford, Surrey \\ AND P. A. MCANULTY \\ Department of Growth and Development, Institute of Child Health, \\ London $W C_{\mathrm{I}} N_{\mathrm{I}} E H$
}

$$
\text { (Received I I March } 1974 \text { - Accepted } 23 \text { May 1974) }
$$

\footnotetext{
1. Weanling male rats were maintained at constant body-weight for $28 \mathrm{~d}$ by feeding them reduced amounts of their normal diet. They were rehabilitated for $0,3,7$, I0 or $16 \mathrm{~d}$, and compared with two sets of control groups, one set of the same body-weight and the other of the same age.

2. The quadriceps, gastrocnemius and anterior tibialis muscles from the left hind-limb were weighed, and DNA, RNA, extracellular protein and intracellular protein estimated in the quadriceps and gastrocnemius muscles.

3. Each muscle responded differently during undernutrition and rehabilitation if compared with 'age controls', but if compared with 'body-weight controls' there was a tendency for muscle weight to remain appropriate for body-weight.

4. The amount of DNA did not change in the gastrocnemius or quadriceps muscles during undernutrition, and on rehabilitation did not begin to increase until after $7 \mathrm{~d}$. RNA decreased during undernutrition, but increased rapidly on rehabilitation. The rate of increase in RNA was greatest in the quadriceps during the first $3 \mathrm{~d}$, but in the gastrocnemius was greatest between 3 and $7 \mathrm{~d}$. The peak values for the rate of RNA increase corresponded with the initiation of intracellular protein accretion in each muscle. Extracellular protein increased during undernutrition, and on rehabilitation, responded in the same way as DNA, that is, it increased only after $7 \mathrm{~d}$.

5. It is concluded that the differences found between muscles of the hind-limb during rehabilitation are due mainly to differences in the rates of DNA and intracellular protein accretion. It is suggested that these differences are the result of a differential response of RNA to rehabilitation.
}

The capacity of skeletal muscle to grow is restricted by undernutrition in animals and man (Mendes \& Waterlow, 1958; Dickerson \& McCance, I960; Montgomery, I962; Cheek, Hill, Cordano \& Graham, I970), and if the muscles are growing rapidly at the onset of undernutrition, they can become very retarded in relation to age (Winick \& Noble, I966). Individual muscles mature at different rates, and in the rabbit there appears to be an antero-posterior gradient in the timing of maturation (Vézinhet, Rouvier, Dulor \& Cantier, r972). There appears to be little information on other animals, but Hammond (1932) found in the sheep that the rates of maturation also vary within a discrete area such as the hind-limb, for the muscles of the upper part mature later than those of the lower part, and the extensor muscles of each limb segment develop before the flexors. Undernutrition has a differential effect on the muscular system, and those muscles that mature late tend to be affected more than those that mature early (Babinski \& Onanoff, I888; Dickerson \& McCance, I960). Retardation of muscle growth by undernutrition is due to an arrest in nuclear pro- 
liferation and to a reduction in the rate of protein accretion (Mendes \& Waterlow, 1958; Winick \& Noble, 1966; Graystone \& Cheek, 1969; Dickerson, Hughes \& McAnulty, 1972).

The purpose of the present study was to determine the responses of individual muscles of the hind-limb of the weanling rat to a period of undernutrition, and also to monitor the responses of the muscles during the early stages of rehabilitation.

\section{MATERIALS AND METHODS}

Male black-hooded rats were reared in litters of eight pups and weaned at $2 \mathrm{I} \mathrm{d}$ of age. At $24 \mathrm{~d}$ pups falling within a body-weight range of $46^{6-5} \mathrm{I}$ were allocated to one of three groups. The 'experimental' group, consisting of fifty animals, was allowed only sufficient quantities of the normal diet to maintain body-weight. This continued for $28 \mathrm{~d}$. At the end of this period ten of the rats were killed, and the remainder rehabilitated by allowing them ad lib. access to the normal diet. Ten rats were then killed after 3,7 , Io and $16 \mathrm{~d}$ of rehabilitation. Another fifty animals were used as 'age controls', and ten of these were killed at each of the ages of the experimental animals; another fifty animals were 'body-weight controls', and ten were killed at each of the body-weights of the experimental animals.

The animals were killed by chloroform anaesthesia, and the left quadriceps, gastrocnemius and anterior tibialis muscles removed. The muscles were weighed immediately, and the quadriceps and gastrocnemius muscles were cooled rapidly on solid $\mathrm{CO}_{2}$ and stored at $-15^{\circ}$ until analysed chemically.

DNA and RNA of the quadriceps and gastrocnemius muscles were extracted and their content determined as described by McAnulty \& Dickerson (1974). Cellular and extracellular proteins were extracted by a modification of the methods of Robinson (1952) and Dickerson (1960), involving the extraction of cellular proteins from portions of muscle homogenate with $0^{\circ} \mathrm{I} \mathrm{M}$-sodium hydroxide, and then dissolving the residue in $\mathrm{I} \cdot \mathrm{OM}$-sodium hydroxide at $50^{\circ}$ to provide the extracellular protein extract. Both cellular and extracellular protein contents were determined by the method of Lowry, Rosebrough, Farr \& Randall (195I).

\section{RESULTS}

The body-weights of the experimental animals did not change significantly during the period of undernutrition, whereas the 'age controls' increased in weight by $147 \mathrm{~g}$. On rehabilitation, the weight of the experimental animals increased by $110 \mathrm{~g}$ in $\mathrm{I} 6 \mathrm{~d}$, whereas that of the controls increased by only $83 \mathrm{~g}$ between 52 and $68 \mathrm{~d}$ of age.

Comparison with the 'age controls' suggested that undernutrition severely retarded the growth of the three muscles investigated (Table I), and the deficit was not corrected during the first $\mathrm{I} 6 \mathrm{~d}$ of rehabilitation. However, generally the weights of the muscles in the previously undernourished animals were not significantly different from those in controls of the same body-weight. A marked exception to the general finding was that increase in weight of the gastrocnemius was significantly slower than in the 'body-weight controls' during the first $3 \mathrm{~d}$ of rehabilitation. 
Vol. 33

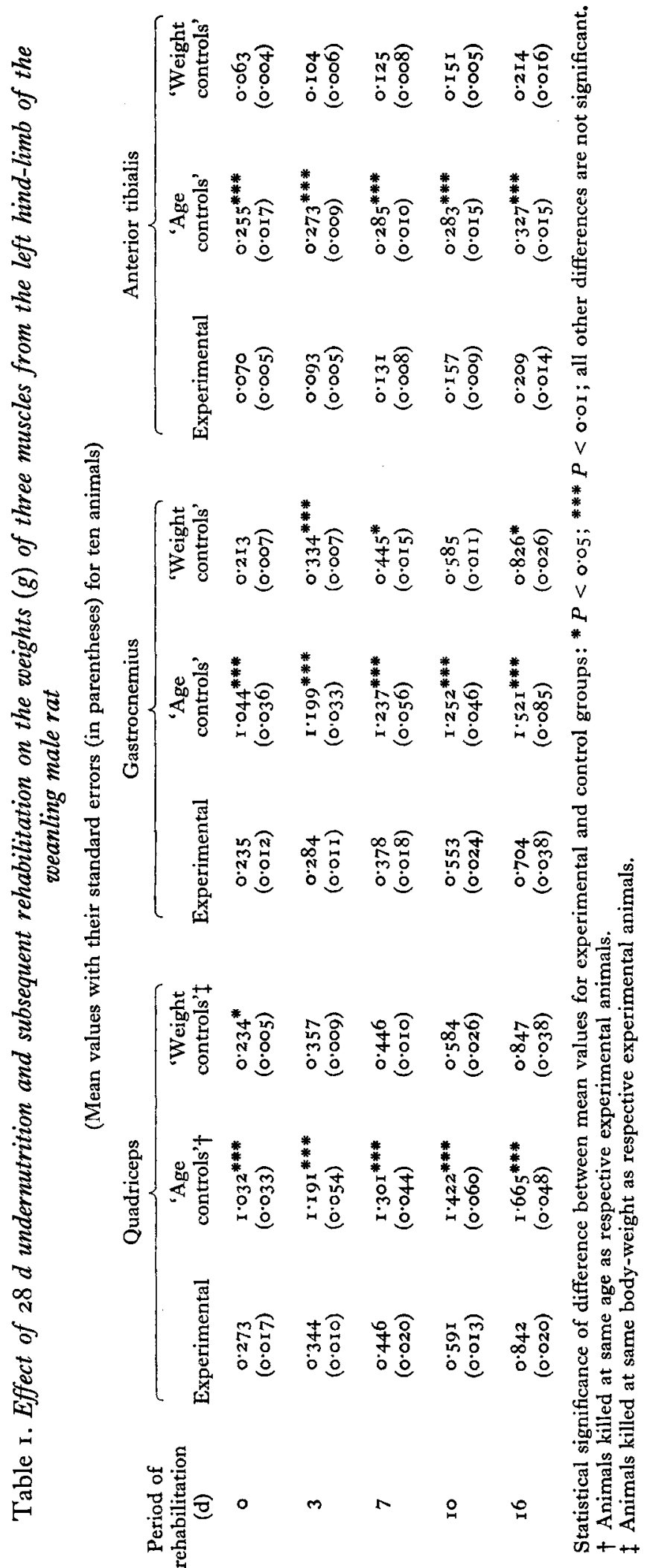




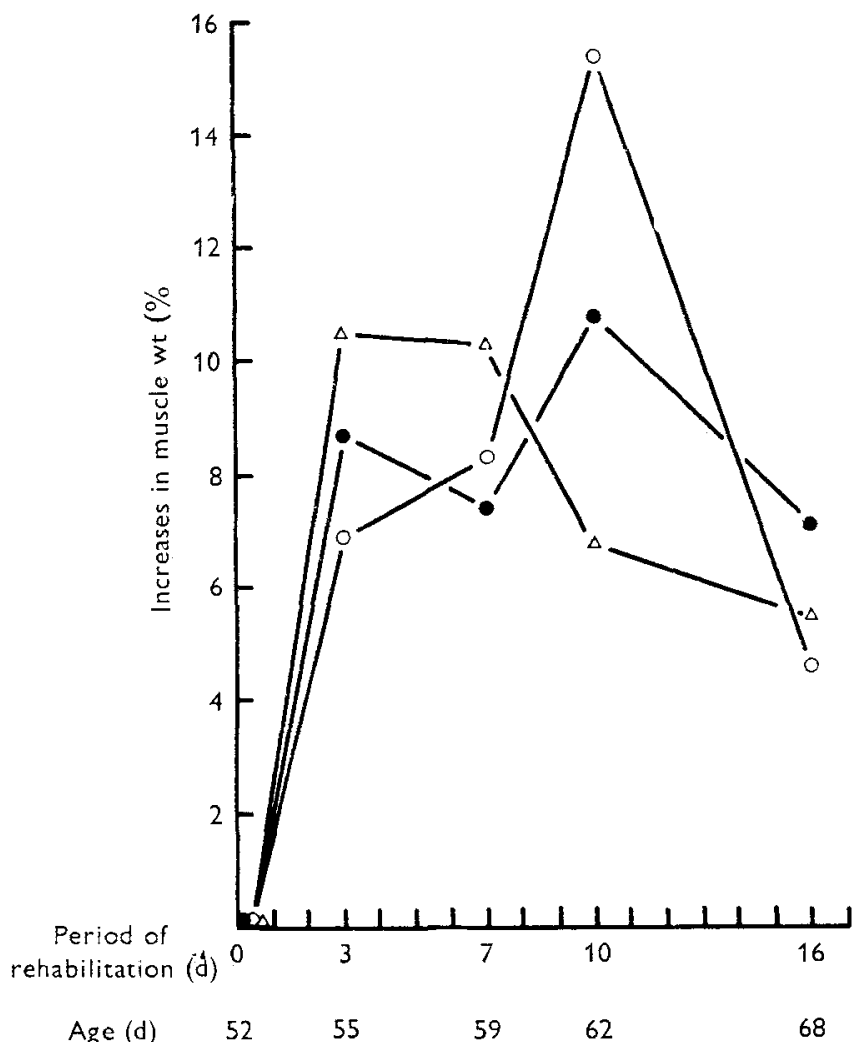

Fig. I. Rates of increase in hind-limb muscle weights during the early rehabilitation of male weanling rats following $28 \mathrm{~d}$ undernutrition. Mean values for the daily increase in muscle weight $(\%)$ over the preceding period from ten animals at each stage of rehabilitation; (O), quadriceps muscle; $(\Delta)$, anterior tibialis muscle; $(O)$, gastrocnemius muscle.

On rehabilitation the pattern of growth was not the same in each muscle (Fig. I), for the anterior tibialis muscle grew most rapidly during the first $3 \mathrm{~d}$, and the gastrocnemius and quadriceps muscles grew most rapidly between 7 and $10 \mathrm{~d}$.

The amount of DNA in the quadriceps (Fig. 2) and gastrocnemius (Fig. 3) muscles did not change significantly during undernutrition, nor did it do so during the first $7 \mathrm{~d}$ of rehabilitation. However, between the $7^{\text {th }}$ and roth day of rehabilitation it rose rapidly in both muscles, and returned to an amount not significantly different from that found in controls of the same body-weight, but it did not reach that found in controls of the same age. In the quadriceps muscle there was a sharp increase in the amount of DNA over the same age interval in the animals being rehabilitated, as in the controls, i.e. $59^{-68} \mathrm{~d}$ of age.

Undernutrition resulted in a decrease, and rehabilitation in a rapid increase, in the amount of RNA in both the quadriceps and the gastrocnemius muscles (Table 2). In the quadriceps, the increase was most rapid during the first $3 \mathrm{~d}$ of rehabilitation, whereas in the gastrocnemius it was between 3 and $7 \mathrm{~d}$. The amount of RNA reached 


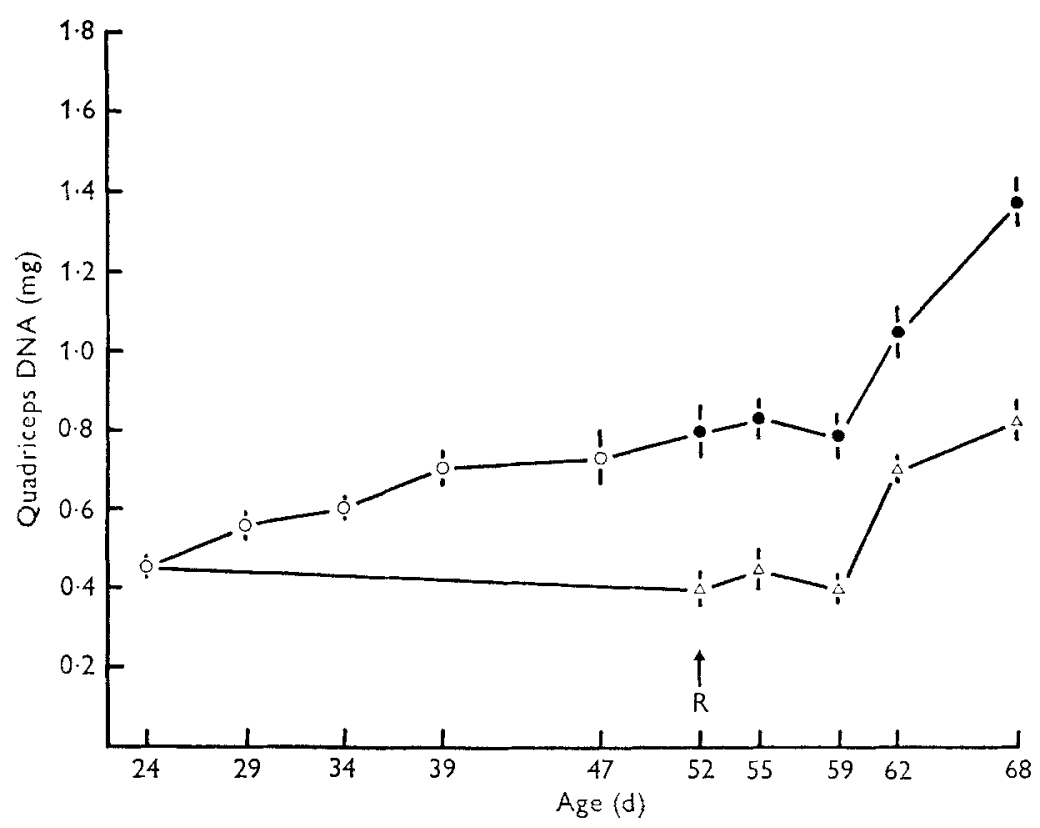

Fig. 2. Amounts of DNA in the quadriceps muscle from the left hind-limb of male weanling rats during normal growth and during undernutrition and rehabilitation. Mean values for ten muscles, with their standard errors indicated by vertical bars. The 'body-weight controls' (animals killed at same body-weight as respective experimental animals) are plotted at their mean ages; $(\triangle)$, experimental; $(O)$, 'body-weight controls'; $(O)$, 'age controls' (animals killed at same age as respective experimental animals); $R$, rehabilitation.

a similar level to that in the 'body-weight controls' within $3 \mathrm{~d}$ of rehabilitation in the quadriceps, and within $7 \mathrm{~d}$ in the gastrocnemius.

The amounts of extracellular protein (Figs. 4 and 5 ) increased significantly in both the quadriceps $(P<0.05)$ and the gastrocnemius $(P<0.001)$ muscles during undernutrition, although there was great variation in the amounts at the end of the period of undernutrition. During rehabilitation the pattern of change in the amounts of extracellular protein was similar to that of DNA, not changing during the first $7 \mathrm{~d}$, but thereafter increasing. In neither muscle did the amount return to that found in the 'age controls'. In the gastrocnemius muscle the amount of extracellular protein was not significantly different from that found in the 'weight controls' throughout rehabilitation. In the quadriceps muscle, however, it was similar at 7 and $\mathrm{Io} d$, more at $3 \mathrm{~d}(P<0.0 \mathrm{I})$ and less at $16 \mathrm{~d}(P<0.00 \mathrm{I})$.

There was very little variation in the amount of intracellular protein (Table 3 ) during undernutrition, when compared with the 'weight controls', and on rehabilitation it increased steadily in the quadriceps muscle, whereas in the gastrocnemius muscle there was an initial lag of $3 \mathrm{~d}$ before accretion began. The amount of intracellular protein in the quadriceps was similar to that in the 'weight controls' throughout rehabilitation, and there was also a tendency for this to be so in the gastrocnemius muscle, after the initial $3 \mathrm{~d}$ lag in accretion.

The intracellular protein:DNA ratio increased slightly in both the quadriceps and 


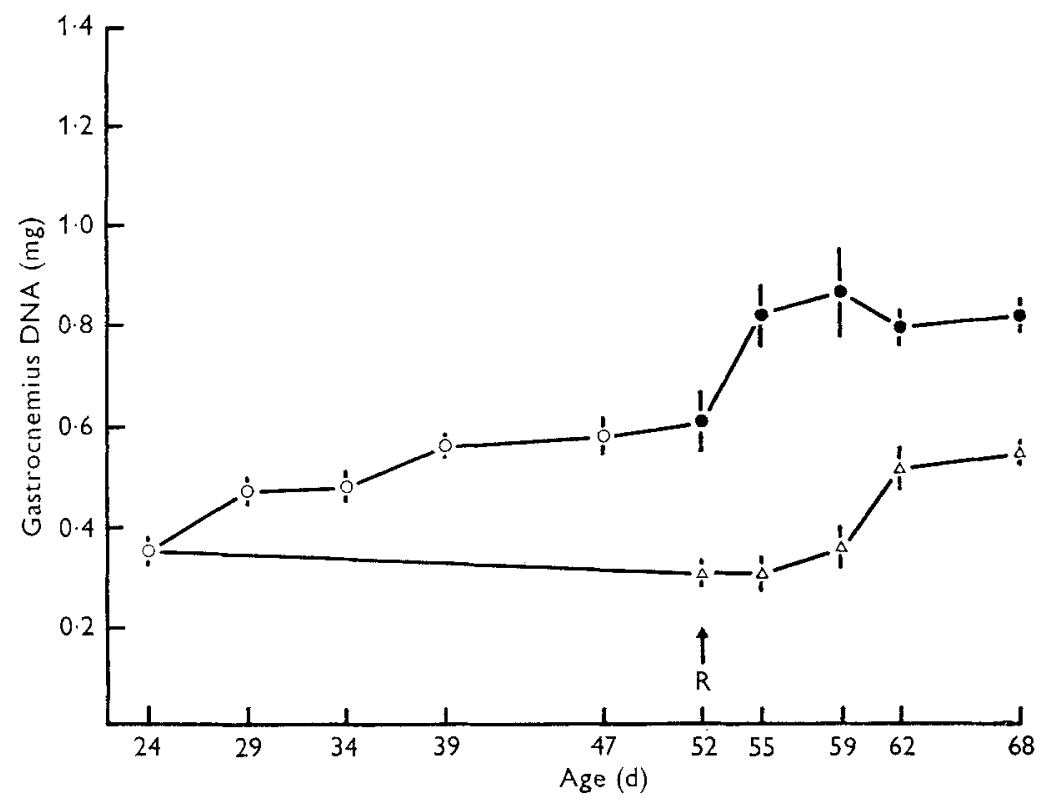

Fig. 3. Amounts of DNA in the gastrocnemius muscle from the left hind-limb of male weanling rats during normal growth and during undernutrition and rehabilitation. Mean values for ten muscles, with their standard errors indicated by vertical bars. The "bodyweight controls' (animals killed at same body-weights as respective experimental animals) are plotted at their mean ages; $(\Delta)$, experimental; $(O)$, 'body-weight controls'; $(O)$, 'age controls' (animals killed at same age as respective experimental animals); $R$, rehabilitation.

Table 2. Effect of $28 d$ undernutrition and subsequent rehabilitation on the amounts of RNA (mg) in the quadriceps and gastrocnemius muscles from the left hind-limb of the weanling male rat

(Mean values with their standard errors (in parentheses) for ten muscles)

Period of rehabilitation

(d)

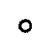

3

7

Io

I6

\begin{tabular}{|c|c|c|}
\hline \multicolumn{3}{|c|}{ Quadriceps } \\
\hline Experimental & $\begin{array}{c}\text { 'Age } \\
\text { controls' } \uparrow\end{array}$ & $\begin{array}{l}\text { 'Weight } \\
\text { controls' }\end{array}$ \\
\hline $\begin{array}{c}0.36 \\
(0.05)\end{array}$ & $\begin{array}{l}I \cdot 80^{* * * *} \\
(0.15)\end{array}$ & $\begin{array}{l}0.63^{* * * *} \\
(0.01)\end{array}$ \\
\hline $\begin{array}{c}0.72 \\
(0.04)\end{array}$ & $\begin{array}{l}I \cdot 7 I^{* * * *} \\
(0 \cdot 20)\end{array}$ & $\begin{array}{c}0.83 \\
(0.04)\end{array}$ \\
\hline $\begin{array}{c}0.96 \\
(0.05)\end{array}$ & $\begin{array}{l}I \cdot 88^{* * * *} \\
(0 \cdot 17)\end{array}$ & $\begin{array}{c}1.07 \\
(0.04)\end{array}$ \\
\hline $\begin{array}{c}I \cdot 39 \\
(0 \cdot 04)\end{array}$ & $\begin{array}{l}2 \cdot 38^{* * * *} \\
(0 \cdot 15)\end{array}$ & $\begin{array}{c}1.45 \\
(0.06)\end{array}$ \\
\hline $\begin{array}{c}2.25 \\
(0.05)\end{array}$ & $\begin{array}{l}3.00 * * * \\
(0.14)\end{array}$ & $\begin{array}{l}1 \cdot 43^{* * * *} \\
(0.10)\end{array}$ \\
\hline
\end{tabular}

Statistical significance of difference between mean values for experimental and control groups: *** $P<0.001$; all other differences are not significant.

$\uparrow$ Animals killed at same age as respective experimental animals.

$\ddagger$ Animals killed at same body-weight as respective experimental animals. 


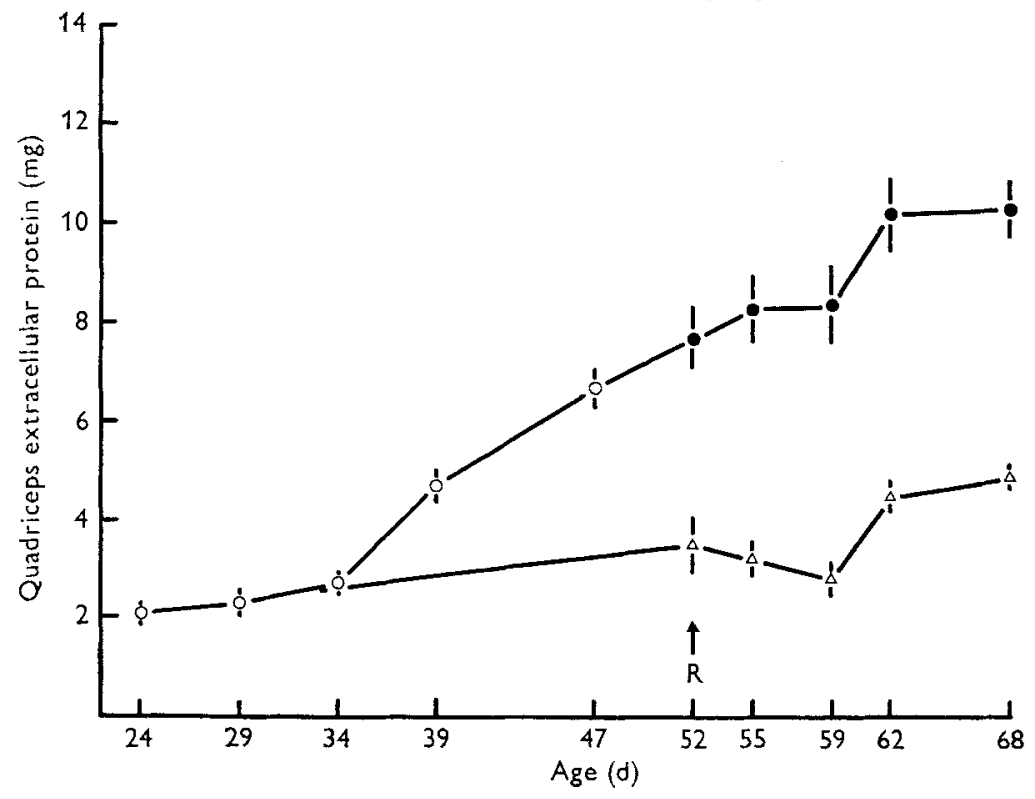

Fig. 4. Amounts of extracellular protein in the quadriceps muscle from the left hind-limb of male weanling rats during normal growth and during undernutrition and rehabilitation. Mean values for ten muscles, with their standard errors indicated by vertical bars. The 'body-weight controls' (animals killed at the same body-weight as respective experimental animals) are plotted at their mean ages; $(\triangle)$, experimental; $(O)$, 'body-weight controls'; (O), 'age controls' (animals killed at same age as respective experimental animals); $\mathbf{R}$, rehabilitation.

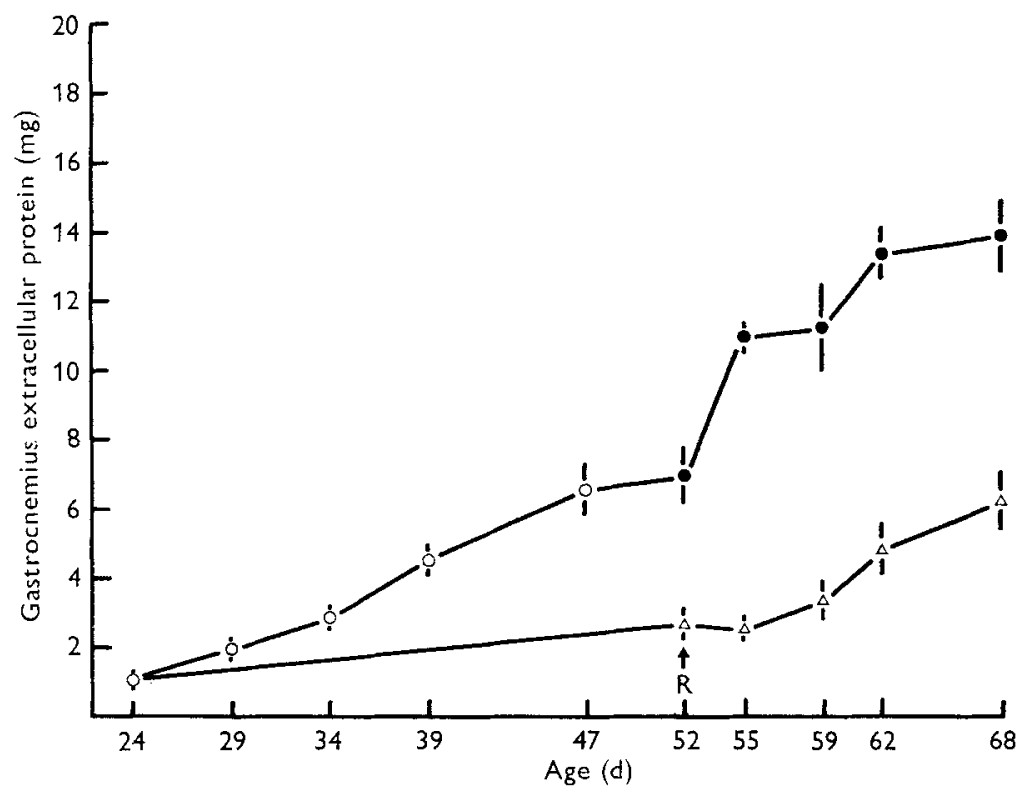

Fig. 5. Amounts of extracellular protein in the gastrocnemius muscle from the left hind-limb of male weanling rats during normal growth and during undernutrition and rehabilitation. Mean values for ten muscles, with their standard errors indicated by vertical bars. The 'bodyweight controls' (animals killed at same body-weight as respective experimental animals) are plotted at their mean ages; $(\triangle)$, experimental; $(O)$, 'body-weight controls'; ( $O$ ), 'age controls' (animals killed at same age as respective experimental animals); $R$, rehabilitation. 
Table 3. Effect of $28 d$ undernutrition and subsequent rehabilitation on the amounts of intracellular protein ( $\mathrm{mg}$ ) in the quadriceps and gastrocnemius muscles from the left hind-limb of the weanling male rat

(Mean values with their standard errors (in parentheses) for ten muscles)

\begin{tabular}{|c|c|c|c|c|c|c|}
\hline \multirow{2}{*}{$\begin{array}{l}\text { Period of } \\
\text { rehabilitation } \\
\text { (d) }\end{array}$} & \multicolumn{3}{|c|}{ Quadriceps } & \multicolumn{3}{|c|}{ Gastrocnemius } \\
\hline & Experimental & $\begin{array}{c}\text { 'Age } \\
\text { controls' } \dagger\end{array}$ & $\begin{array}{l}\text { 'Weight } \\
\text { controls' }\end{array}$ & Experimental & $\begin{array}{l}\text { 'Age } \\
\text { controls' }\end{array}$ & $\begin{array}{l}\text { 'Weight } \\
\text { controls' }\end{array}$ \\
\hline$\circ$ & $\begin{array}{l}55 \\
(4)\end{array}$ & $\begin{array}{l}18 z^{* * * *} \\
(9)\end{array}$ & $\begin{array}{l}44^{* *} \\
(\mathrm{I})\end{array}$ & $\begin{array}{l}57 \\
(3)\end{array}$ & $\begin{array}{l}215^{* * *} \\
\text { (10) }\end{array}$ & $\begin{array}{l}52 \\
(2)\end{array}$ \\
\hline 3 & $\begin{array}{l}71 \\
(5)\end{array}$ & $\begin{array}{l}214 * * * \\
(14)\end{array}$ & $\begin{array}{l}64 \\
(I)\end{array}$ & $\begin{array}{l}63 \\
(5)\end{array}$ & $\begin{array}{c}243^{* * * *} \\
(8)\end{array}$ & $\begin{array}{l}76^{* * * *} \\
(2)\end{array}$ \\
\hline 7 & $\begin{array}{l}91 \\
(7)\end{array}$ & $\begin{array}{l}253^{* * * *} \\
\text { (12) }\end{array}$ & $\begin{array}{l}76 \\
(2)\end{array}$ & $\begin{array}{l}88 \\
(4)\end{array}$ & $\begin{array}{l}269^{* * *} \\
(\mathrm{I} 2)\end{array}$ & $\begin{array}{l}95 \\
(3)\end{array}$ \\
\hline Io & $\begin{array}{l}\mathrm{IO} 4 \\
(5)\end{array}$ & $\begin{array}{c}262 * * * * \\
(8)\end{array}$ & $\begin{array}{l}99 \\
(3)\end{array}$ & $\begin{array}{l}112 \\
(2)\end{array}$ & $\begin{array}{l}287^{* * * *} \\
(8)\end{array}$ & $\begin{array}{l}\text { I } 27^{* *} \\
(4)\end{array}$ \\
\hline 16 & $\begin{array}{c}142 \\
(3)\end{array}$ & $\begin{array}{c}266 * * * * \\
(9)\end{array}$ & $\begin{array}{r}159 \\
(8)\end{array}$ & $\begin{array}{l}170 \\
\left(\mathrm{I}_{3}\right)\end{array}$ & $\begin{array}{l}306 * * * \\
\left(\mathrm{I}_{4}\right)\end{array}$ & $\begin{array}{c}175 \\
(3)\end{array}$ \\
\hline
\end{tabular}

gastrocnemius muscles during undernutrition, but in both muscles the ratio was too low for age. The ratio returned to values found in both 'weight' and 'age controls' within $16 \mathrm{~d}$ of rehabilitation.

\section{DISCUSSION}

When male rats were maintained at a constant body-weight by feeding them reduced quantities of their normal diet, the growth restriction had a variable effect on the muscles of the hind leg. Moreover, when the retarded animals were rehabilitated, each muscle had an individual pattern of recuperative growth, which was probably due to the fact that muscles grow and mature at different rates (Hammond, 1932; Vézinhet et al. 1972).

There was, however, a tendency for the muscles to maintain their correct weight relative to body-weight. Similar findings have been reported for the muscles of farm animals (Wallace, 1948; Elsley, McDonald \& Fowler, r964; Butterfield \& Johnson, 197I), and for other organs (McAnulty \& Dickerson, 1973, 1974). The weight of both the quadriceps and the anterior tibialis muscles remained similar to those of control animals of the same body-weight during rehabilitation, and therefore followed the normal growth pattern. However, in these rehabilitating rats the muscles grew faster than in the controls, for they took $16 \mathrm{~d}$ in comparison with the $23 \mathrm{~d}$ taken by the controls to complete this phase of relative muscle growth.

The gastrocnemius and quadriceps muscles grew at their fastest between 7 and ro d of rehabilitation (Fig. I), when there were also sharp increases in the amount of DNA. The testes are also growing at their fastest rate at this stage of rehabilitation 
(McAnulty \& Dickerson, 1974), and thus the spurt in muscle weight and DNA synthesis may be the result of increased levels of circulating androgenic hormones (Cheek, Brasel \& Graystone, 1968). Spurts also occurred in DNA synthesis in the muscles of the control rats, and this has been referred to as a 'pubertal' spurt (Cheek, Powell \& Scott, 1965). The timing of the spurt in DNA synthesis in the gastrocnemius corresponds closely with spurts in body-weight and hind-leg length (Hughes \& Tanner, 1970), and the male rat may therefore have an adolescent growth spurt similar to that in man (Tanner, 1962 ).

Muscle fibres are polynucleate, and since there is little increase in the number of muscle fibres in the rat after birth (Enesco \& Puddy, 1964), the increases in DNA reported in this paper reflect increases in the number of nuclei per muscle fibre, the nuclei presumably being derived from satellite cells (Moss \& Leblond, 1971).

In agreement with previous studies there was no change in the amount of DNA during undernutrition (Graystone \& Cheek, r969; Hill, Holt, Parra \& Cheek, I970), and the protein:DNA ratio increased slightly (Cheek \& Hill, I970).

The amount of protein in the quadriceps and gastrocnemius muscles increased during undernutrition, due largely to an increase in the amount of extracellular protein. An increase in extracellular protein has been reported previously (Mendes \& Waterlow, 1958; Dickerson \& McCance, I960; Montgomery, Dickerson \& McCance, I964), and is accompanied by an increase in extracellular water as measured by the chloride or sodium 'space' (Dickerson \& McCance, 1960; Montgomery et al. 1964). On rehabilitation there was a lag in extracellular protein accretion until the amount present was appropriate for muscle weight.

The accretion of intracellular protein in the gastrocnemius and quadriceps muscles during rehabilitation occurred in parallel with rises in the amounts of RNA. In the quadriceps the amounts of both increased during the first $3 \mathrm{~d}$, whereas in the gastrocnemius there was a lag period, similar to that reported by Howarth $\&$ Baldwin (1971). These authors have shown that in the gastrocnemius the failure of protein synthesis during initial rehabilitation is probably due to a deficiency in the number of microsomes and in the amount of microsomal RNA. The superior response of protein and RNA synthesis found in the quadriceps suggests that the microsomal deficiency may be corrected more rapidly in the quadriceps than in the gastrocnemius.

Thus, the variations in muscle growth during rehabilitation were accompanied by corresponding changes in the rates of intracellular protein and RNA accretion. The rate of accretion of extracellular protein and DNA were similar in both muscles during rehabilitation. It has been suggested that protein synthesis in muscle is under the general control of insulin (Cheek \& Hill, I970), and if this is so, a further control mechanism must exist at the level of the individual muscles, in order that they can respond differently. There is evidence that this further mechanism is a factor, or factors, located in the cell sap (Manchester, 1972).

This research was supported by the Medical Research Council through a long-term grant to Professor J. M. Tanner. We would like to thank Professor Tanner for his interest in this work and for his suggestions during the preparation of this paper. 


\section{REFERENCES}

Babinski, M. J. \& Onanoff, M. (1888). C. r. Séanc. Soc. Biol. 5, r45.

Butterfield, R. M. \& Johnson, E. R. (I 97I). F. agric. Sci., Camb. 76, 457.

Cheek, D. B., Brasel, J. A. \& Graystone, J. E. (I968). In Human Growth p. 306 [D. B. Cheek, editor]. Philadelphia: Lea \& Febiger.

Cheek, D. B. \& Hill, D. E. (I970). Fedn Proc. Fedn Am. Socs exp. Biol. 29, I503.

Cheek, D. B., Hill, D. E., Cordano, A. \& Graham, G. G. (1970). Pediat. Res. 4 , 135.

Cheek, D. B., Powell, G. K. \& Scott, R. E. (1965). Fohns Hopkins Hosp. Bull. r17, 306.

Dickerson, J. W. T. (1960). Biochem. F. 75, 33.

Dickerson, J. W. T., Hughes, P. C. R. \& McAnulty, P. A. (1972). Br. F. Nutr. 27, 527.

Dickerson, J. W. T. \& McCance, R. A. (1960). Br. F. Nutr. 14, 331 .

Elsley, F. W. H., McDonald, I. \& Fowler, V. R. (1964). Anim. Prod. 6, I4I.

Enesco, M. \& Puddy, D. (1964). Am. F. Anat. 114, 235.

Graystone, J. E. \& Cheek, D. B. (1969). Pediat. Res. 3, 66.

Hammond, J. (1932). Growth and Development of Mutton Qualities in the Sheep. Edinburgh: Oliver and Boyd.

Hill, D. E., Holt, A. B., Parra, A. \& Cheek, D. B. (1970). Fohns Hopkins Hosp. Bull. 127, 146.

Howarth, R. E. \& Baldwin, R. L. (1971). $\mathscr{~}$. Nutr. ror, 477.

Hughes, P. C. R. \& Tanner, J. M. (1970). F. Anat. 106, 349.

Lowry, O. H., Rosebrough, N. J., Farr, A. L. \& Randall, R. J. (195 I). F. biol. Chem. I93, 265.

McAnulty, P. A. \& Dickerson, J. W. T. (1973). Pediat. Res. 7, 778.

McAnulty, P. A. \& Dickerson, J. W. T. (1974). Br. F. Nutr. 32, 30 .

Manchester, K. L. (1972). Diabetes 21, Suppl. 2, 447.

Mendes, C. B. \& Waterlow, J. C. (1958). Br. Y. Nutr. 12, 74.

Montgomery, R. D. (1962). F. clin. Path. 15, 5 II.

Montgomery, R. D., Dickerson, J. W. T. \& McCance, R. A. (I964). Br. F. Nutr. 18, 587.

Moss, F. P. \& Leblond, C. P. (197I). Anat. Rec. 170, 42 I.

Robinson, D. S. (1952). Biochem. F. 52, 621 .

Tanner, J. M. (1962). Growth at Adolescence and ed. Oxford: Blackwell.

Vézinhet, A., Rouvier, R., Dulor, J.-P. \& Cantier, J. (1972). Annls Biol. anim. Biochim. Biophys. 12, 33.

Wallace, L. R. (r948). F. agric. Sci., Camb. 38, 93.

Winick, M. \& Noble, A. (1966). 7. Nutr. 89, 300 . 